Acta Regionalia et Environmentalica 1

Nitra, Slovaca Universitas Agriculturae Nitriae, 2015, pp. 11-14

\title{
SOCIAL ASPECTS OF RURAL COMMUNITY DEVELOPMENT
}

\author{
Věra MAJEROVÁ \\ Czech University of Life Sciences Prague, Czech Republic
}

\begin{abstract}
A well-balanced relationship between economic and social progress is the main prerequisite of rural community stability. Economic development is influenced by many factors. Some of these are statistically discoverable and quantifiable, while others, which fall within the sphere of social relations and their identification, are more difficult to measure and interpret. Czech rural areas face many problems which arise from their specific features - socio-demographic structure, job possibility of various social groups, provision of the proper level of public services, transport accessibility, etc. However, there is no direct connection between economic factors and mutual relations within the rural community. Values, opinions and the behavioural patterns of people are immediately displayed in a locality, but their character is shaped by the regional and national assumptions of every stage of development. Contributions are drawn from the accessible literature and secondary data of empirical research projects.
\end{abstract}

Keywords: rural community development, social relations

A well-balanced relationship between economic and social development is the main prerequisite of rural community stability. However, no development can be uniform and linear. The CR's affiliation to the EU brought about a complexity of various effects; some of these are evaluated unambiguously as being positive, while others are evaluated with embarrassment. Economic rating is easier, because the majority of indicators are quantifiable and methods of measurement are elaborated. In the social sphere, the measurement and interpretation of indicators are more difficult. Czech rural areas struggle with many problems, which result from their specifics - sociodemographic structure, possibilities for different social groups to find employment, ensuring of an adequate level of public services, transport accessibility, etc. In any case, it is impossible to seek a direct dependence between the economic factors and the mutual relations within the rural community. The values, opinions and behaviour of people are manifested in the first instance in the locality, but their character is shaped by the regional and national presuppositions of any developmental phase.

\section{Material and methods}

Finding sufficient data for credible thinking about rural areas' development is laborious and difficult. Only some data exist in the social statistics: i.e. socio-demographic indicators, unemployment rate, crime rate, level of health care expressed by the number of hospitals and health institutions, educational level expressed by the number of schools, etc. The development of employment over the past ten years and the search for the effects of fluctuating unemployment in rural areas are pursued from the viewpoint of nationwide statistics. This information is presented yearly in the Green Report of the Czech Ministry of Agriculture.

Data on opinions, attitudes, values and behaviour of the rural population would have to be obtained by sociological research projects, which are very expensive. At present it is difficult, almost impossible, to obtain financing for representative samples. Contributions partially result from the publication, "Values, attitudes, behaviour. Social report of European social survey - ESS" (Vlachová, 2013), which provides data on the national level. We can deduce which aspects are significant and important for Czech rural areas, particularly in the light of their future progress.

For explanatory and interpretative purposes of the development in the Czech Republic and Slovakia, the data from ESS are used. Data on Poland and the average of EU countries are mentioned for comparison. Data are related to the particular countries as a whole (without the geographical division into urban and rural areas), because this analytical step is not allowed by their structure. Social aspects of rural development are interpreted only in the form of hypotheses, which could be tested in the future. The basic method is deduction with the use of secondary analysis.

\section{Results and discussion}

\section{Economic transition of agriculture and its impact}

The socialistic large-scale agricultural epoch claimed that the ideological concept is more important over the economic reality. The principles of market economy were marginalised; the inadequate employment of the rural population was maintained; different economic results of regions as well as agricultural enterprises (state and co-operative) were 
subsidised from the state budget. Agriculture ensured high employment in rural areas; however, this depended on massive state support.

Gradual transitional steps (from the return of collectivised land and property to the change in the proprietary structure of enterprises) led to rationalisation on the principles of market economy. The result was growing competition (national as well as international) and uncertainty of agricultural workers within the framework of the national economy. The most sensitive question was the growing competition on the labour market. Parts of the rural population have inferior educational structure compared to the average in the Republic; some professional specialisations are hardly usable in other branches and the accessibility of suitable jobs is difficult in rural areas. The largest decrease in work stations occurred after 1989 However, also in approximately the past 10 years, it can be observed that the proportion of people employed in agriculture remains low.

Nevertheless, the employability of some social groups is difficult. The socio-demographic structure of the rural population does not respond to the demands of transformed enterprises and the competitive environment of the contemporary labour market. There is a persistence of the lack of suitable work stations for those who are professionally narrowly specialised, less educated, older or handicapped (agriculture is one of the branches with a high proportion of work injuries and job-related illnesses). The possibilities of employment are reflected in the earnings of the rural population, which is $91.8 \%$ of the total gross income average and $92.8 \%$ of the net income of the Czech population. Compared with the population of big cities, this deficit is still higher. Lower incomes are also connected with the factual demand of rural households (Mátl and Srnová, 2012).

The political change in 1989 was a trigger for economic transition. Similarly to other post-socialist countries, the Czech Republic also shows the standard political power rotation of right-wing and left-wing parties. Growing unemployment generally initiates civic discontent and the accrual of support for left-wing parties, because of rising unemployment results in a lower standard of living, lower consumption, etc. However, the political situation in the Czech Republic is marked for its relative stability within the context of the post-socialist countries.

\section{Social aspects of rural spatial development}

Since the Czech Republic's membership in the EU, rural development has been influenced by a support policy for less favoured areas. Structural funds assist in increasing the competitive advantages of specific European regions and improving the quality of life. The viewpoint of endowment priorities has gradually changed from technical and environmental issues in the scale of the activities supported (improving regional infrastructure, diversification of economic subjects, nature conservation, etc.) and has extended to the social sphere.

The national development priorities of the Czech Republic post-2013 are:

- Increasing the competitiveness of the economy;

- Developing a backbone infrastructure;

- Improving the quality and efficiency of public administration;

- Promoting social inclusion, healthcare system, and combating poverty;

- Integrating regional development (Mátl and Srnová, 2012).

Let us focus on the last two points, which are related to the social sphere, even if the economic context is obvious. Social exclusion and inclusion, the healthcare system and combating poverty is a broad range, which is increasingly meaningful in the rural areas. There are not sufficient empirical data which could be used for the evaluation of the rural areas. The majority of considerations are therefore derived from broader and more general data, relating to the Czech population (including international comparisons) and related only to some chosen spheres of life.

\section{Prerequisites of working and family life in the countryside}

One of the basic indicators of a contented life in the countryside is a good job, which gives a man financial security, certitude, self-fulfilment, provides professional contacts for

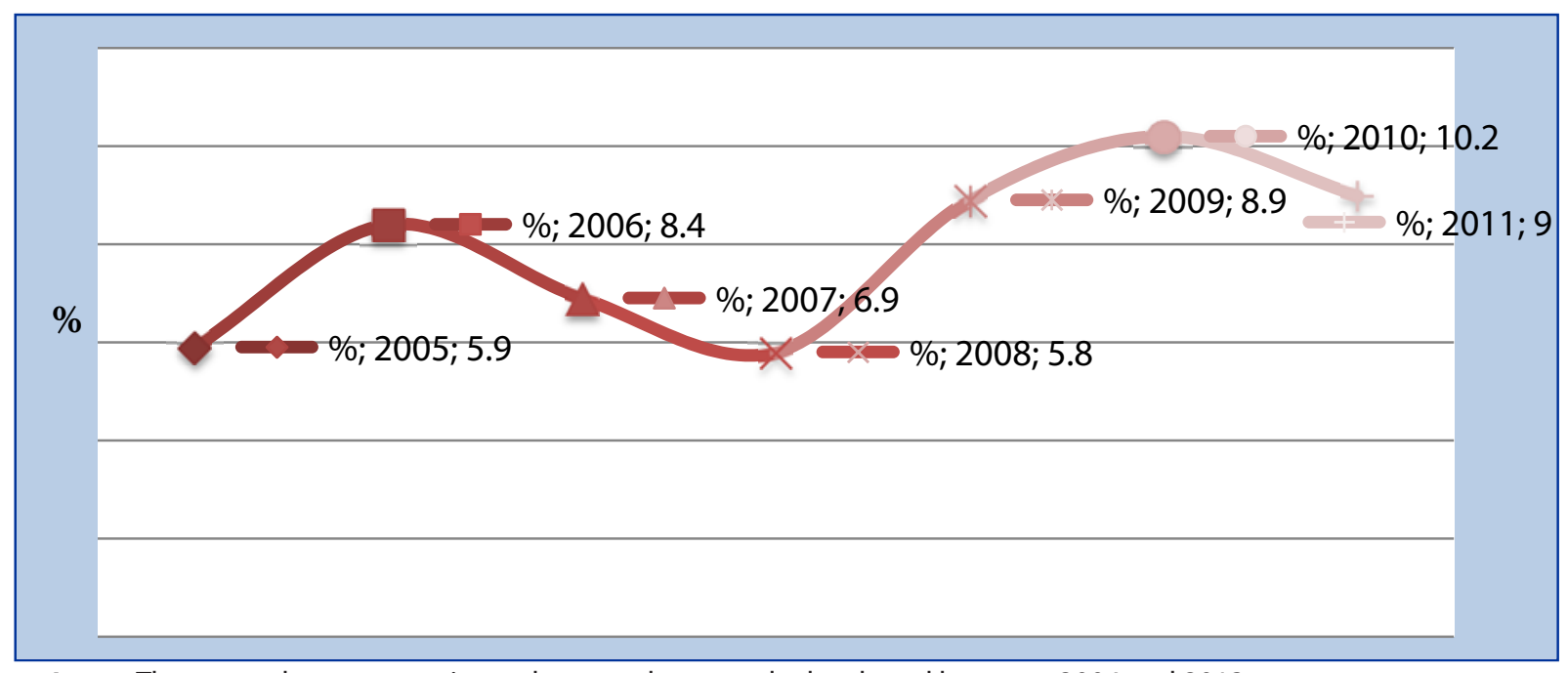

Figure 1 The unemployment rate in rural areas subsequently developed between 2004 and 2013 Source: Green Report of CR 2005, 2006, 2007, 2008, 2009, 2010, 2011, 2012, 2013, Ministry of Agriculture 
him/her and, at the same time, is not so exhausting that he/she has no energy either for family life or civic activities in a village. Since 1989, a part of the rural population has taken advantage of entrepreneurship (including private farming) and used its knowledge and capabilities in this sphere. The extent of work involvement is given by two basic factors: own decision or demand of an employer. If a person organises his/her own work, it is his/her own decision whether to work more or less. If he/she is an employee, he/she must conform to the requests of his/her employer, which can be time-consuming in a competitive environment. Conflict between work and family can lead to the total exhaustion of the worker and also to the detriment of his/her own family.

Data concerning purely the rural areas are not at our disposal. That is why the data from the

European Social Survey (Vlachová, 2013) were used and compared with our close neighbours (Poland and Slovakia). International comparison of the three countries shows that the conflict between work and private life was felt by men as well as women in the Czech Republic, and in particular more strongly felt in Poland.

If we consider the working possibilities in rural areas and the specificities of rural life (living in the family houses, ownership of garden and plots), then it is possible to presume that the work problems are connected with the uncertainty of a permanent job in the locality and accessible vicinity, and possibly with commuting. Apart from the care of children and the household, on the scale of additional activities, family duties include work connected with the house and plot: cleaning and maintenance of a large and more dilapidated residence, cultivation of the garden, care of domestic animals, processing, storage and conservation of fruit, vegetables and other produce. Tensions concerning work and family life can increase. Men in all the selected countries experience more stress. This is also indicative of the nature of their roles in the family, household and employment.

Average satisfaction with the balance between time spent at work and time devoted to other things was measured on the ten-step scale. Developed countries, such as Denmark,

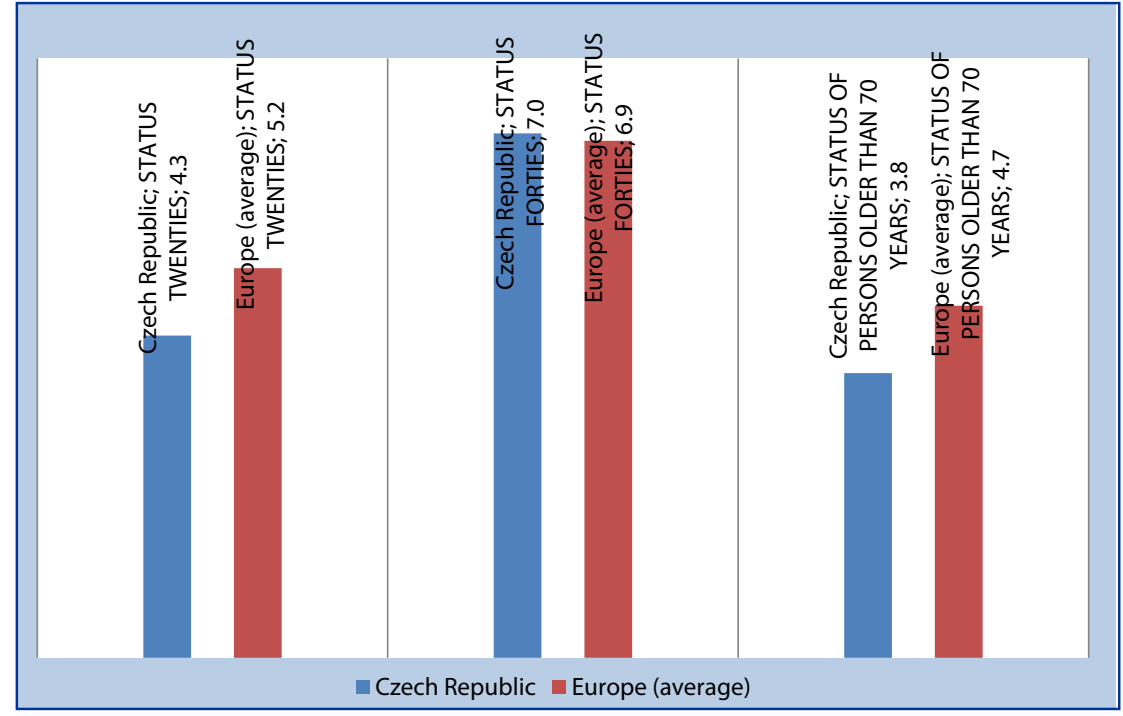

Figure 2 Average ages' status in the Czech Republic and in Europe (range 0-10) Source: Vlachová, K. (ed.): Values, attitudes, behaviour. Social Report of the European Social Survey - ESS, p. 41

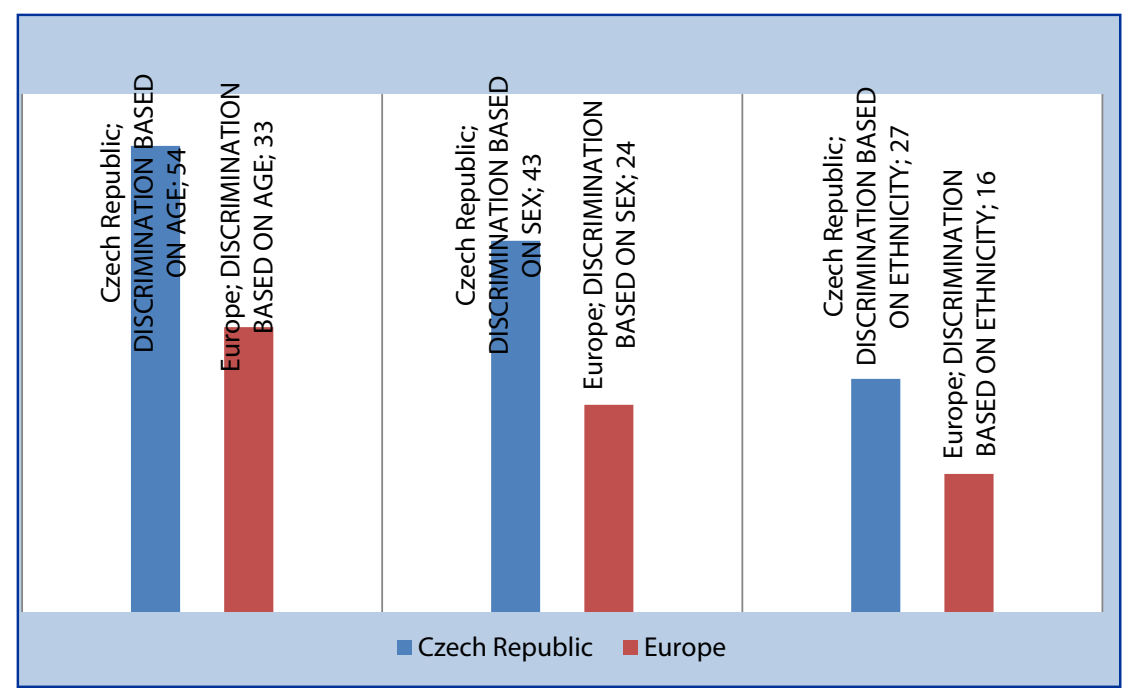

Figure 3 The proportion of people with experience of selected types of discrimination in \%

Source: Vlachová, K. (ed.): Values, attitudes, behaviour. Social Report of the European Social Survey - ESS, p. 31

Switzerland, Finland, The Netherlands, Belgium and Norway, have the highest level of satisfaction. Among the selected countries, satisfaction is on the same level in Poland and Slovakia; in the Czech Republic, it is somewhat lower and approaching countries such as Ukraine and Russia.

\section{Prerequisites of personal satisfaction \\ and well-balanced relationship with society}

Social appreciation is another necessary prerequisite of a contented life, apart from the material living conditions and emotional relationships within the family. Social appreciation is a reflection of how others perceive one's place in society, including all the components.

On the opposite pole of social evaluation are biases, discrimination and deprecation of individuals by society. If we use the analogical fission of discriminating factors, the most superable are those factors which can be changed by one's own decision (i.e. religion, nationality, poor qualifications, different manners, etc.). The discriminating behaviour of society towards the congenital disposition (gender, age, race, ethnicity, physical features) is more difficult to be reframed. 
Although discrimination is most often mentioned in connection with ethnicity, religion and skin colour, it appears that age discrimination is more extensive. In the Czech Republic, 40-year-old people have roughly the same social status as this age group in other European countries. However, the social status of the younger and older age groups is lower than in other European countries (average of Europe 27). We may state that terminal age groups are less accepted by society. The social status of people aged over 70 years is lower than the status of 20-year-olds.

From the findings of the ESS comparative research, it appears that, in the Czech Republic as well as across the whole of Europe, ageism is the most extensive form of discrimination in comparison with gender and ethnicity.

The definition of ageism is as follows: "Ageism can be understood as the process of systematic stereotyping and discrimination of people due to their increased age, similarly to the way in which racism and sexism are related to skin colour and gender. Old people are categorised as senile, rigid in their thinking and behaviour, devalued in morale and skills..." (Pešák, 2007). The Czech Republic can be considered as a country in which the negative attitude towards older people is fairly strong.

There is no doubt that the shaping of social attitudes is connected with the general economic and social situation of every state, official propaganda, influence of mass media, strategy of social services, methods to solve unemployment, and other factors. The necessity of the increasing costs of social services (including retirement pensions) within the context of the state national debt is emphasised too often in the Czech reality. On one hand, increasing the retirement age is advocated and, on the other hand, working pensioners are seen as the reason for youth unemployment. Specific age groups are viewed antagonistically and the presumption is strengthened that some people live at the expense of others.

Data extracted from the ESS are not possible to be sorted according to geographic aspects. We can only speculate whether and to what extent age discrimination also occurs in rural areas. Differences are apparent relevant to the size of localities. Smaller villages generally have a higher average population age. In a more homogeneous age structure, however, disagreement can occur. However, we do not assume age to be the main reason for this disagreement. Age discrimination is more probable in a population of heterogeneous age, especially when the different age groups are dependent on each other and often have social contact.

Czech seniors hold (perforce voluntarily) offices in public service and partake in local functions. To increase the quality of life of all social groups and prevent age discrimination, it would be useful to revise the level of legislative protection of seniors in all stages of their lives, to make possible their compulsory age-appropriate employment (if it is helpful to them as well as to society) and, above all, to derive benefit from their knowledge and experience for the improvement of social life in the village. This can assist them to increase their social status within the framework of both the family and the community.

\section{Conclusion}

Ten years after the Czech Republic's accession to the EU, some trends in economic and social development continue. The proportion of people permanently employed in agriculture has decreased. The attitude towards employment is changing; the rural population has not ensured its lifetime in large-scale agriculture enterprises. It must seek new employment in the locality as well as in the surroundings. Transmigration for the sake of employment is not typical in the CR. The competitive environment of the labour market places higher demands on workers. The tension between work stress and family duties is increasing.

There are similar trends in social life in the CR as in other European countries (EU-27). Age discrimination is more distinct than discrimination for other reasons. Economically active people have a higher social status. The social status of seniors is decreasing more markedly in the CR than in the rest of Europe. The average population age is higher in rural areas. For this reason, the development of rural municipalities always depends on the co-operation of social groups of all ages. Material preconditions are an important basis. However, without legislative support and shared moral principles, development efforts cannot be successful.

\section{Acknowledgements}

The information introduced in this paper resulted from the implementation of project IGA No. 20131036, in the Faculty of Economics and Management, Czech University of Life Sciences Prague: Involving citizens of rural communities in public life.

\section{References}

http://cs.wikipedia.org/wiki/Soci\%C3\%A1/n\%C3\%AD_status MÁTL, O., SRNOVÁ, E.: Budoucnost venkova v České republice: Analýza potřeb obcí po roce 2013 z hlediska budoucí kohezní politiky a společné zemědělské politiky. Praha: Svaz měst a obcí České republiky, 2012, pp. 36. Accessible at: http://www.smocr.cz/ cz/publikace/default.aspx

PEŠÁK, A.: Změny v sociálním postavení ve stáří - sociální exkluze a ageismus ve vztahu k mobilitě http://www.czrso.cz/clanky/zmenyv-socialnim-postaveni-ve-stari-socialni-exkluze-a-agei/, 2007

SOUHRN ke Zprávě o stavu zemědělství ČR za rok 2013, Ústav zemědělské ekonomiky, pp. 2. Praha, 2014.

VLACHOVÁ, K. (ed.): Hodnoty, postoje, chování. Česká republika 2002 - 2012. Sociální report projektu European social survey. Sociologický ústav AV ČR, Praha 2013. ISBN 978-80-7330-224-5

ZAMĚSTNANOST a nezaměstnanost $v$ ČR podle výsledků VŠPS (2004 - 2013), ČSÚ. Accessible at: http://www.czso.cz/ csu/2014edicniplan.nsf/publ/250132-14-r_2014

ZPRÁVA o stavu zemědělství ČR za rok 2004 - 2012, Accessible at: http://eagri.cz/public/web/mze/zemedelstvi/ publikace-a-dokumenty/zelene-zpravy/ 